\title{
Treatment of Ventricular Tachycardia Induced by Coil of Ventricular Lead of Implantable Cardioverter Defibrillator
}

Tratamento de Taquicardia Ventricular Induzida por Mola de Choque de Eletrodo de Cardioversor Desfibrilador Implantável

William Oliveira de Souza ${ }^{1, *}$, Pablo Ferreira Reis ${ }^{1}$, Fábio Lopes Erthal', Rodrigo Minati Barbosa'

ORCID IDs

Souza WO (iD https://orcid.org/0000-0001-7828-1867

\section{ABSTRACT}

Implantable cardioverter defibrillator (ICD) -DDD for arrhythmogenic heart disease of unknown etiology, with the induction of ventricular tachycardia by the right ventricle (RV) of the shock electrode. The arrhythmia generated by the ICD electrode itself was the cause of multiple episodes with appropriate anti-tachycardia pacing (ATP) and shock therapy. The etiology of the arrhythmia was confirmed by electrophysiological study and successful treatment was performed with ablation, without the need for surgical repositioning of the electrode.

KEYWORDS: Cardiac arrhythmias; Ventricular tachycardia; Implantable defibrillators; Implanted electrodes; Catheter ablation; Postoperative complications

\section{RESUMO}

Paciente portador de cardioversor desfibrilador implantável (CDI)-DDD por cardiopatia arritmogênica de etiologia desconhecida, com indução de taquicardia ventricular pela mola de ventrículo direito (VD) do eletrodo de choque. A arritmia gerada pelo próprio eletrodo do CDI foi causa de múltiplos episódios com terapia apropriada por anti-tachycardia pacing (ATP) e choque. Confirmada a etiologia da arritmia por estudo eletrofisiológico e realizado tratamento bem-sucedido com ablação, sem necessidade de reposicionamento cirúrgico do eletrodo.

PALAVRAS-CHAVE: Arritmias cardíacas; Taquicardia ventricular; Desfibriladores implantáveis; Eletrodos implantados; Ablação por cateter; Complicações pós-operatórias.

1.Instituto Nacional de Cardiologia- Rio de Janeiro/RJ - Brazil.

*Correspondence author: wodsouza@gmail.com Received: 06 Apr 2018 | Accepted: 04 Feb 2019 Section Editor: J.Tarcísio Medeiros de Vasconcelos 


\section{INTRODUCTION}

An interesting case is reported by the induction of ventricular arrhythmia by the device that aims to treat it. The treatment was performed with radiofrequency catheter ablation, without the need for surgical repositioning of the electrode.

\section{METHODS}

The patient is followed up at the Arrhythmia Service of the Instituto Nacional de Cardiologia (National Institute of Cardiology), in the state of Rio de Janeiro. The case was set up with a review of records, electrophysiological studies, and anamnesis. Bibliographical review ${ }^{1-3}$. Search in the PubMed database with the terms «implantable cardioverter defibrillator lead complications», «icd lead replacement», «icd leadinduced arrhythmia», «icd coil induced arrhythmia» did not return similar cases until 04/05/2018.

\section{CASE REPORT}

Patient ACJ, male, 45 years old in 2010, attended in a public emergency care unit with sustained monomorphic ventricular tachycardia (SMVT) and hemodynamic instability, being treated with electrical cardioversion (ECV) and the event classified as analogous to aborted sudden death. Referred to specialized service of the Sistema Único de Saúde-SUS (Unified Health System). In April 2011, he was admitted to the Arrhythmia Service of the Instituto Nacional de Cardiologia and was hospitalized for further investigation. The examinations at the time showed echocardiogram with the absence of structural heart disease, normal coronariography, ergometric test with ventricular bigeminism at the peak of the effort (9.6 mets) and two 24-hour Holter exams with several episodes of nonsustained ventricular tachycardia (NSVT). Was chosen an electrophysiological study with SMVT re-induction, an initially stable cycle of $290 \mathrm{~ms}$ (207 bpm), with acceleration and instability after antitachycardia pacing (ATP) with a need for ECV. In the same hospitalization, the patient was implanted with an implantable cardioverter defibrillator (ICD) - DDD with a double-spring shock electrode (Biotronik Lumax 340 DRT, Biotronik Linox SD 65/16 shock electrode, Briotronik Setrox S53 atrium electrode).

In December 2011, the patient was re-admitted with an electrical storm picture by multiple SMVT. Interrogation of the device demonstrated that all therapies were appropriate. After adjustment of drugs and cessation of arrhythmias, the patient was discharged. At the time, the possibility of an electrophysiological study and ablation (EPS/ABL) was questioned, depending on the posterior clinical evaluation. However, it evolved without new arrhythmias until the generation unit was exhausted in 2014, is submitted to the exchange of this (Medtronic Virtuoso II DR), maintaining the electrodes.

In February 2017, the patient sought care due to a shock. Interrogation of the device revealed about 200 episodes of tachyarrhythmia, most of NSVT, a minority of SMVT interrupted with ATPs and one episode of failure in successive ATPs and appropriate shock. New EPS/ABL was scheduled within one week and the drugs were adjusted, but the patient progressed without any arrhythmia episode, and the procedure for observation was canceled.

In August of the same year, the patient returned with> 2,000 episodes of NSVT and SMVT. All sustained arrhythmias were discontinued ATPs. New echocardiogram maintained the absence of identifiable structural heart disease. It was then submitted to EPS/ ABL with electroanatomic mapping. Prior to the procedure, ICD therapies were deactivated and the unit reprogrammed to VVI mode $30 \mathrm{bpm}$ (pacing suppression), and the patient was in sinus rhythm throughout the procedure. Voltage map showed an absence of endocardial scars. EPS easily induced NSVT and SMVT, with a cycle of $315 \mathrm{~ms}$ (190 bpm), hemodynamic stability and interruption with ATP. The electroanatomic mapping observed a region of greater precocity attached to the proximal portion of the $\mathrm{RV}$ shock spring. In this region, precocity, mesodiastolic potential and 12/12 similarity in the pace mapping maneuver were observed. This region was determined as the focus of the presented arrhythmia, radiofrequency applications juxtaposed to the shock spring endocardially on both sides of it as a «rail», with a higher concentration of applications in the medial and proximal aspect of the spring (Fig.1). 
After the end of the applications, ventricular arrhythmia was no longer induced. At the end of the procedure, ICD interrogation demonstrated the stability of the right ventricular (RV) electrode impedance and shock spring, suggesting that the radiofrequency application, although juxtaposed, did not inflict damage to the electrode. Returned to the previous programming procedure. It evolved with stability, receiving a discharge after $48 \mathrm{~h}$ of the procedure, and in the use of amiodarone $200 \mathrm{mg} /$ day, bisoprolol $10 \mathrm{mg} /$ day and ramipril $2.5 \mathrm{mg} /$ day. Return in one week did not show any new arrhythmias. Last evaluation in September 2017, with no new arrhythmia episodes (Table 1).

\section{DISCUSSION}

The implantation of electronic cardiac devices is expanding, revealing new challenges in clinical practice. The presence of arrhythmias in the postoperative period of implantation of implantable cardiac electronic devices has been known for a long time and is expected to improve after 48 hours after the procedure. ${ }^{4}$ In the previous experience of the Instituto Nacional de Cardiologia, SMVT was already observed on ICD shock electrodes, however with an origin at the tip of the electrode ${ }^{5}$, site of known fibrosis and possible arrhythmogenic complications. The case presented is relevant

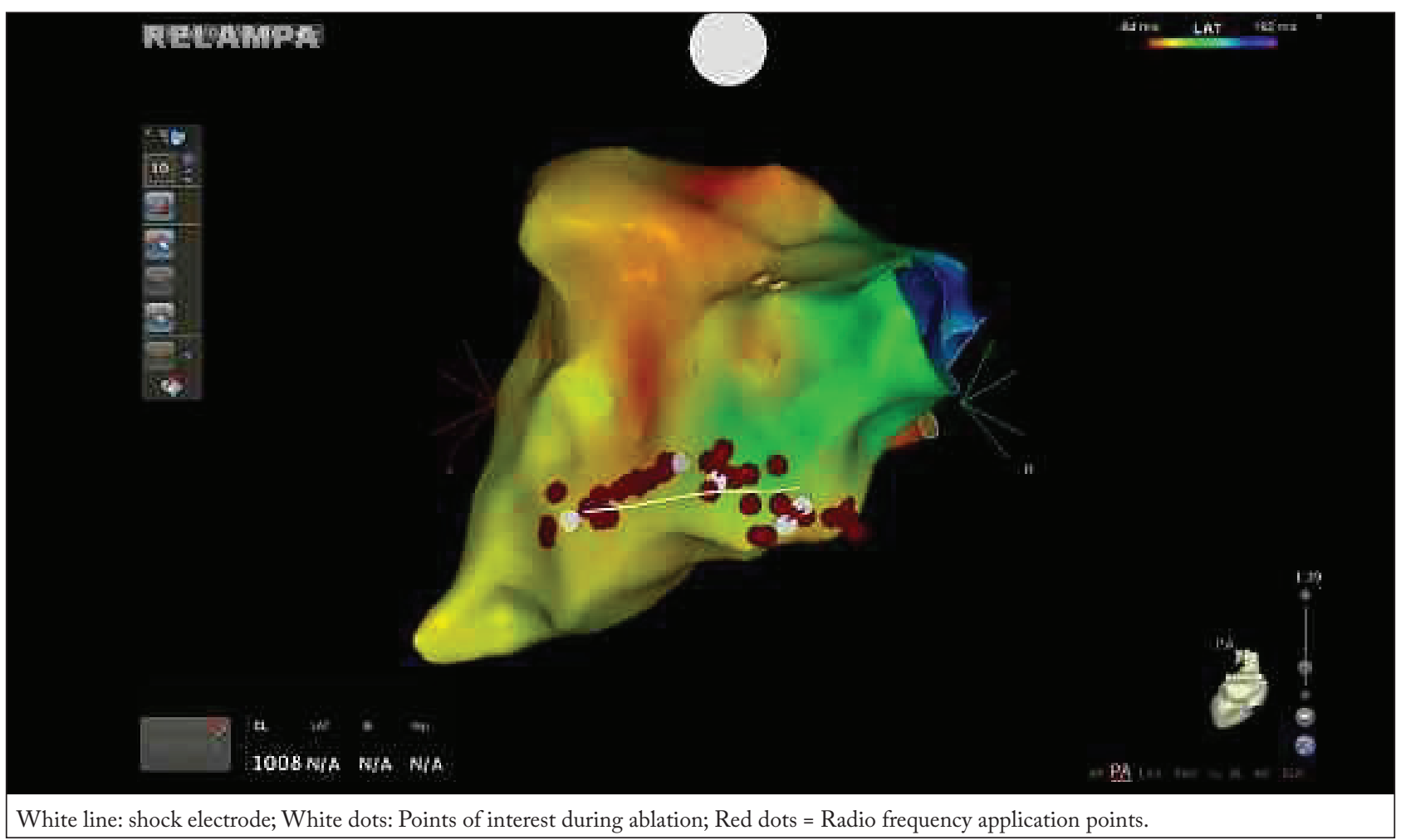

Figure 1. Electroanatomic mapping in sinus rhythm.

Table 1. ICD Interrogation, ablation in 18 August 2017.

\begin{tabular}{|c|c|c|c|c|c|}
\hline Events & $\begin{array}{c}26 \text { May } 2017 \\
\text { to } \\
28 \text { July } 2017\end{array}$ & $\begin{array}{c}28 \text { July } 2017 \\
\text { to } \\
18 \text { August } 2017\end{array}$ & $\begin{array}{l}18 \text { August } 2017 \\
\text { to } \\
25 \text { August } 2017\end{array}$ & $\begin{array}{c}25 \text { August } 2017 \\
\text { to } \\
29 \text { Setember } 2017\end{array}$ & $\begin{array}{l}\text { Total since } \\
8 \text { July } 2017\end{array}$ \\
\hline Ventricular fibrillation & 0 & 0 & 0 & 0 & 0 \\
\hline $\begin{array}{l}\text { Fast ventricular } \\
\text { tachycardia }\end{array}$ & 0 & 0 & 0 & 0 & 26 \\
\hline Ventricular tachycardia & 43 & 114 & 0 & 0 & 247 \\
\hline $\begin{array}{l}\text { Non-sustained } \\
\text { ventricular } \\
\text { tachycardia }\end{array}$ & 2033 & 2817 & 0 & 0 & Non-available data \\
\hline $\begin{array}{l}\text { Anti-tachycardia } \\
\text { pacing }\end{array}$ & 43 & 114 & 0 & 0 & 272 \\
\hline Shocks & 0 & 0 & 0 & 0 & 1 \\
\hline
\end{tabular}


for the documentation of arrhythmia caused by the contact of the shock spring with the endocardium. The presence of precocity to the electroanatomic mapping, as well as the successful treatment with ablation in the target region, strongly suggests the origin of this arrhythmia in the RV shock spring. It is not clear whether the arrhythmia, in this case, was caused only by the presence of contact of the shock spring with the endocardium or if the patientss previous arrhythmogenic condition contributed to its induction, since the etiology of the arrhythmia that led to the index event in 2010 and the electrical storm in 2011 was not defined. It is important to point out that the SMVT morphologies obtained in the EPS of 2011 and 2017 are different in cycles and morphologies, suggesting distant foci.
Radiofrequency catheter ablation was effective in suppressing the occurrence of repeated NSVT episodes and inappropriate therapies, without the need for surgical repositioning of the shock electrode.

\section{ACKNOWLEDGMENTS}

To Prof. Bernardo Rangel Tura, for the review of the article.

\section{AUTHORS' CONTRIBUTION}

All the authors contributed equally to this article.

\section{REFERENCES}

1. Ellenbogen KA, Neal Kay G, Lau CP. Clinical cardiac pacing, defibrillation, and resynchronization therapy. 3a ed. Philadelphia: Saunders; 2007.

2. Melo CS. Tratado de estimulação cardíaca artificial. 5a ed. Tamboré: Manole; 2015.

3. Al-KhatibSM, Stevenson WG, Ackerman MJ, BryantWJ, Callans DJ, Curtis AB, et al. 2017 AHAACC/HRS guideline for management of patients with ventricular arrhythmias and the prevention of sudden cardiac death. Circulation. 2018;138(13):e272-e391.

https://doi.org/10.1161/CIR.0000000000000549

4. Brito Junior HL, Gauch PRA, Oliveira AS de. Arritmias induzidas por marcapasso cardíaco. JBAC. 1990;3(3):88-93.

5. Souza WO, Seifert MMS, Pinho DL, Nascimento EAD, Saad EB, et al. Anais do $28^{\circ}$ Congresso de Cardiologia da Socerj; 3-5 de Agosto de 2011; Rio de Janeiro. 